\title{
The uncertainties underlying herd immunity against COVID-19
}

\author{
Farid Rahimi ${ }^{* *}$ and Amin Talebi Bezmin Abadi ${ }^{2 *}$ \\ 1 Research School of Biology, The Australian National University, Canberra, Australia; \\ farid.rahimi@anu.edu.au \\ 2 Department of Bacteriology, Faculty of Medical Sciences, Tarbiat Modares University, Tehran, Iran; Amin \\ amin.talebi@modares.ac.ir \\ * Correspondence: farid.rahimi@anu.edu.au; Tel.: +61-2-6125-2851 (F.R.); amin.talebi@modares.ac.ir; Tel.: \\ $+98-8288-4883$ (A.T.B.A.)
}

\begin{abstract}
Herd immunity happens when a relatively large proportion of a population becomes infected by an agent, subsequently recovers, and attains immunity against the same agent. That proportion thus indirectly protects the naïve population by preventing the spread of the infection. Herd immunity has been suggested to interrupt and control the COVID-19 pandemic. However, relying on establishing herd immunity can be catastrophic considering the virulence and lethality of SARS-CoV-2. Meanwhile our understanding of the pathogenesis, case-fatality rate, transmission routes, and antiviral therapy for COVID-19 remains limited now. Interrupting or slowing the COVID-19 transmission seems more opportune than vaccination, antiviral therapy, or herd immunity, all of which will take some time to yield. Thus, social distancing, face-masking, and hygiene are the most appropriate immediate countermeasures. Because the social fabrics, economic implications, and local demands of various nations are unique, early relaxation of restrictions may seem hasty particularly when fatality rates are high, or when the healthcare systems could be inadequate or become inundated. Conclusively, avoiding any overwhelmingly risky approach in fighting the pandemic is prudent.
\end{abstract}

Keywords: COVID-19; herd immunity; pandemic; pathogenesis; SARS-CoV-2; WHO

\section{The pandemic and the disease, the novel coronavirus disease 2019}

Wuhan, capital of the Hubei Province, China, became infamous after December 2019 when the first cluster there of patients with "pneumonia of unknown cause" were reported to the World Health Organization (WHO) [1]. The patients presented with severe acute respiratory distress and recounted their participation in the Chinese spring festival or their attendance at the live markets of game animals, meat, and seafood [2,3]. Although the initial cases of this illness were not considered serious by the local authorities, the subsequent cases eventually convinced not only the Chinese government but also the WHO to urge a coordinated core attempt for managing a potential global outbreak. The cause of the pneumonia was discovered later to be a new virus, which was initially dubbed 2019-nCoV and then SARS-CoV-2 [4]. By 11 March 2020, the novel coronavirus disease 2019 (COVID-19) had travelled the world widely, from Japan to the United states and from Tehran to the New York City, spanning almost 210 countries; then, WHO upgraded the outbreak's status from epidemic to pandemic [5]. WHO classified the risk level as "Very High" back on 24 March 2020 [6], and as of 30 June, 10,278,458 positive cases were confirmed globally (according to the John Hopkins' Coronavirus Resource Center [7]).

The new virus, which is a member of the Coronaviridae, has proven to be a formidable threat to the global human life and the way of living [8-11]. SARS-CoV-2 has a significant genomic identity with the bat coronaviruses, and a zoonotic transmission mode (at least by direct contact between an 
animal and a human) has been postulated, but the intermediate hosts have not been identified [11-13]. Furthermore, SARS-CoV-2 persists to some extent, similarly to SARS-CoV-1, on environmental and material surfaces (e.g., aerosols, plastics, stainless steel, copper, and cardboard) [14]. As for the COVID-19 symptoms, pyrexia, dry cough, sore throat, expectoration and sometimes hemoptysis, dyspnea, malaise, anorexia, and myalgia have been the most common [15,16]. While our understanding of the disease has been improving, additional clinical features, symptoms, or associations of the disease have been recognized with time [17-21]. Hence, 1) neurological, psychiatric, neuropsychiatric, and cerebrovascular presentations such as loss of taste and smell, anxiety, delirium, dementia-like symptoms, and stroke events; 2) gastrointestinal issues such as loss of appetite, nausea, and diarrhea; 3) dermatological signs such as peripheral chilblain-like lesions; 4) urinary effects such as collapsing glomerulopathy and cystitis; and 5) multisystem inflammation, a Kawasaki-like syndrome, and cardiovascular events reportedly present with COVID-19 [20,22-36]. Predictably, such symptoms reflect the distribution of the receptor for SARS-CoV-2, the angiotensin-converting enzyme 2 (ACE2) and potentially that of ACE2's partner - the neutral amino acid transporter B ${ }^{0}$ AT1 (SLC16A19) - in the human tissues [23,37,38].

Some epidemiological features of the virus, such as its global spread and infectivity - also likely by the unpredictable asymptomatic carriers [39] and subjects with milder respiratory symptoms or with subclinical manifestations [39] - could have been boosted by the stability and persistence of the virus in the environment [14]. Forty percent of the cases may have been due to transmission by the asymptomatic carriers [40]. The COVID-19 experiences of Italy and South Korea support the unpredictable nature of the pandemic [14,41,42]. While the entire uninfected population in the five continents are likely immune-naïve and susceptible to the virus, continuous caution and preparation are needed for controlling subsequent incidence peaks of the infection because not all regions have been restricted, and when easing of restrictions and reopening of economies will inevitably ensue. Both aggressive and widespread contact-tracing for early detection of the cases should continue to reduce the disease burden nationally and internationally [8]. Thus far, the countermeasures implemented to deal with the COVID-19 outbreak have included in-house self-isolation, barring mass-gatherings, working from home, remote or online teaching/learning, development of potential vaccines or antiviral agents, and reliance on the emergence of herd immunity [43,44]. All these approaches have their limitations and strengthens. In this Communication, we summarize the uncertainties shrouding the herd-immunity concept in tackling the COVID-19 pandemic. Encouraging or discouraging herd immunity is a pivotal public-health debate in the fight against SARS-CoV-2.

\section{Herd immunity against COVID-19}

When a large fraction of a population is infected by a certain microorganism - naturally or by vaccination-and recovers afterwards, the individuals' immune systems are expected, collectively, to thwart subsequent exposures; this phenomenon is called herd immunity $[45,46]$. During the COVID-19 pandemic, the British government was the first to refer to this strategy, but later withdrew their proposal following the strong criticism by the scientific and medical communities and social media [47,48]. A slightly similar approach was adopted by the Dutch and Swedish governments. This concept is now challenging the public-health decision-makers in several other countries. Intervening by herd immunity implies that some people may have to host the virus potentially for months while no vaccine or efficient antiviral drug is available. This consideration seems risky despite some researchers' showing that an immune response could be induced against SARS-CoV-2 infection in the experimental ferrets, rhesus macaques, and in the COVID-19 patients [49-51]. Therefore, letting herd immunity take control is a well-grounded postulate.

The course of the pandemic in Iran, which was one of the first countries that was hit hard by the first peak of this outbreak, is potentially a good example. Figure 1 shows two incidence peaks of the epidemic in Iran. These are unfortunately mirrored by a similar trend in the fatalities, suggesting that a proportion of the 80 million Iranian residents may have attained herd immunity gradually; otherwise, hundreds of thousands more people would have succumbed to the rapid viral spread by 
initially reported case-fatality rates (CFRs). However, extensive serological testing of the population is necessary to confirm this postulate.

Meanwhile, the present general evidence on production of antibodies in symptomatic or asymptomatic subjects and the longevity of such antibodies against SARS-CoV-2 has been debated $[52,53]$. Also, some relevant aspects of the pathobiology of the virus are still unknown. For example, the definite mortality rate due to COVID-19 will take time to be determined. Estimates suggest this to be around $8 \%$ in some populations [54]. However, considerable differences in the CFR have been recorded in different regions because of the variations and inconsistencies in the level of the public-health measures or healthcare. High fatality rates could also reflect comorbidities [55] that complicate patients' vulnerability and prognoses. Information on the CFR is crucial for determining the effectiveness of herd immunity in the fight against the pandemic. For herd immunity to succeed, $60-70 \%$ [56] or $80 \%$ of a regional population should ideally be infected and subsequently survive the disease. Providing effective and long-lasting antibodies and immune memory are produced and maintained, one can only hope to reach a certain number of immune people in the face of the fatalities. However, this will take a relatively long time with potentially many lives lost along the way. Letting the virus loose to cause loss of lives is grossly unethical.

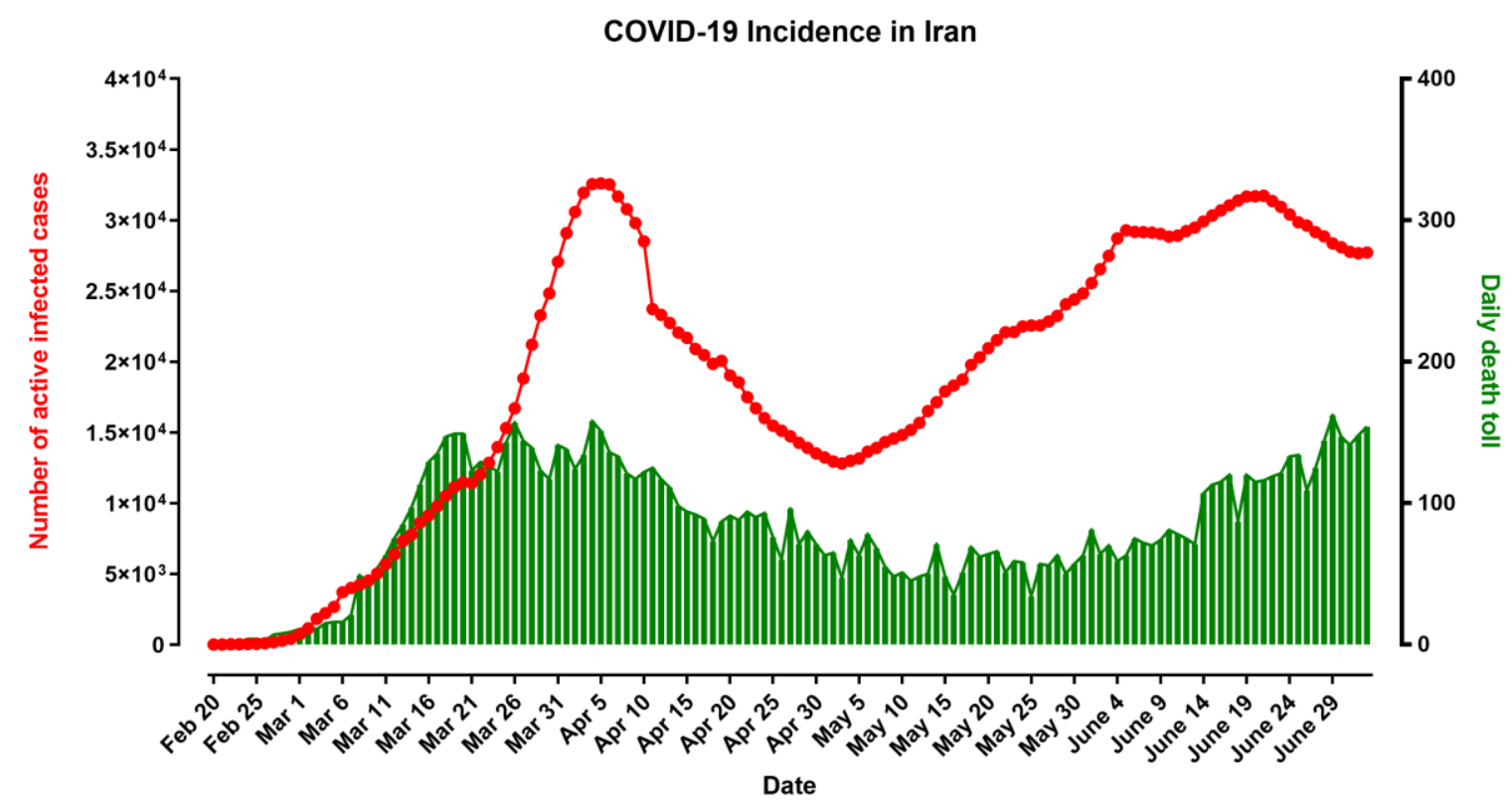

Figure 1. Number of active (left y-axis) and daily death toll (right y-axis) of the COVID-19 cases in Iran graphed until 3 June 2020 (source: [57]).

Immunologically, SARS-CoV-2 is new to humans; thus, grave outcomes are expected as have been documented throughout the world so far. As of 30 June 2020, 10,278,458 positively confirmed cases with almost 480,000 death toll proves the widespread and successful dissemination of the virus. The cumulative knowledge about COVID-19 suggests that its pathogenesis and virulence differ from other viral or bacterial infections so that it may not be controlled by herd immunity. The present lack of knowledge on the pathogenesis, CFR, transmission routes, and lack of antiviral therapies, or lack of vaccination [8] reduces the potential of herd immunity to succeed, at least during the present pandemic. Accordingly, the British Society for Immunology has called for caution [58].

Moreover, the asymptomatic COVID-19 carriers may unintentionally and unknowingly transfer the virus to vulnerable subjects who may eventually suffer severe prognoses [39]. Recent clinical findings suggest that patients with comorbid hypertension, diabetes, cardiovascular diseases, chronic respiratory diseases, and cancer suffer high CFRs [8]. However, data on the viral distribution and antibody production among the potential high-risk or low-risk hosts are lacking. Understanding 
the virulence of the virus is also challenging. Will the virus become more virulent upon evolving with potential mutations while transmitting within a population? The high possibility of seasonal recurrence of COVID-19 should be considered together with the potentially unstable genetic/genomic characteristics of SARS-CoV-2; similarly to influenza virus, SARS-CoV-2 may evolve by mutations as it may re-emerge seasonally or regionally $[59,60]$. Future epidemiological and genetic/genomic studies of the virus may decipher the viral mutation rates and will potentially direct the design and testing of a vaccine against COVID-19.

With the above caveats, reliance on herd immunity now will likely cause a major public-health catastrophe. Many countries will need many hospitals and intensive-care resources to successfully manage the surging numbers of the succumbing COVID-19 patients [61,62].

\section{Conclusions}

Maintaining the balance between the economic repercussions of the restrictions and saving the human lives and livelihoods is a social, ethical, and political debate during the present pandemic. Subsequent to the disagreements and deep concerns raised by the Olympians and their governments, the International Olympic Committee finally announced to postpone the 2020 Tokyo Olympic Games to 2021 [63]. This announcement agrees with the presently recommended physical-distancing and hygiene countermeasures, and active contact-tracing, which are important particularly when the exact CFR is yet unknown. Early easing of the restrictions and reopening of the economies in some of the countries like Iran may lead to a second incidence surge of the pandemic. Reconsidering and revising the public-health policies for managing the COVID-19 pandemic is mandatory. According to one of the latest WHO COVID-19 Situation Reports, almost all of the countries are now invaded by SARS-CoV-2 [6]. Thus, aggressive contact-tracing and shutting down social venues and gatherings will likely prevent the viral spread, though a fraction of the population may expectedly be exposed to SARS-CoV-2 as economies gradually reopen. Interruption of the transmission chain now is arguably easier, timelier, and more practicable than pursuit of herd immunity or development of antiviral or prophylactic therapies - which take longer to yield. Thus, the fight against this pandemic requires pragmatic measures instead of miscalculated, idealistic decisions.

Author Contributions: Conceptualization, F.R and A.T.B.A; investigation, F.R. and A.T.B.A; writing-original draft preparation, A.T.B.A; writing, review, and editing, F.R. and A.T.B.A. Both authors have read and agreed to the published version of the manuscript.

Funding: This research received no external funding.

Acknowledgments: None.

Conflicts of Interest: The authors declare no conflict of interest.

\section{References}

1. The World Health Organization. Pneumonia of unknown cause - China. Availabe online: https://www.who.int/csr/don/05-january-2020-pneumonia-of-unkown-cause-china/en/ (accessed on 20 March 2020).

2. Hui, D.S.; E, I.A.; Madani, T.A.; Ntoumi, F.; Kock, R.; Dar, O.; Ippolito, G.; McHugh, T.D.; Memish, Z.A.; Drosten, C., et al. The continuing 2019-nCoV epidemic threat of novel coronaviruses to global health - The latest 2019 novel coronavirus outbreak in Wuhan, China. Int. J. Infect. Dis. 2020, 91, 264-266, doi:10.1016/j.ijid.2020.01.009.

3. Kock, R.A.; Karesh, W.B.; Veas, F.; Velavan, T.P.; Simons, D.; Mboera, L.E.G.; Dar, O.; Arruda, L.B.; Zumla, A. 2019-nCoV in context: lessons learned? The Lancet Planet Health 2020, 4, e87-e88, doi:10.1016/S2542-5196(20)30035-8.

4. $\quad$ Chan, J.F.; Yuan, S.; Kok, K.H.; To, K.K.; Chu, H.; Yang, J.; Xing, F.; Liu, J.; Yip, C.C.; Poon, R.W., et al. A familial cluster of pneumonia associated with the 2019 novel coronavirus indicating 
person-to-person transmission: a study of a family cluster. Lancet 2020, 395, 514-523, doi:10.1016/S0140-6736(20)30154-9.

5. The World Health Organization. Coronavirus disease 2019 (COVID-19) Situation Report - 51. Availabe online:

https://www.who.int/docs/default-source/coronaviruse/situation-reports/20200311-sitrep-51-covid-19. pdf?sfvrsn=1ba62e57 6 (accessed on 14 April 2020).

6. The World Health Organization. Coronavirus disease 2019 (COVID-19) Situation Report - 64. Availabe online:

https://www.who.int/docs/default-source/coronaviruse/situation-reports/20200324-sitrep-64-covid-19. pdf?sfvrsn=723b221e 2 (accessed on 24 March 2020).

7. Dong, E.; Du, H.; Gardner, L. An interactive web-based dashboard to track COVID-19 in real time. Lancet Infect. Dis. 2020, 20, 533-534, doi:10.1016/S1473-3099(20)30120-1.

8. Fisher, D.; Heymann, D. Q\&A: The novel coronavirus outbreak causing COVID-19. BMC Med. 2020, 18, 57, doi:10.1186/s12916-020-01533-w.

9. Gupta, M.; Abdelmaksoud, A.; Jafferany, M.; Lotti, T.; Sadoughifar, R.; Goldust, M. COVID-19 and economy. Dermatol. Ther. 2020, e13329, doi:10.1111/dth.13329.

10. Dyer, O. Covid-19: Trump declares intention to "re-open economy" within weeks against experts' advice. BMJ 2020, 368, m1217, doi:10.1136/bmj.m1217.

11. Conforti, C.; Cannavo, S.P.; Jafferany, M.; Dianzani, C.; Di Meo, N.; Lotti, T.; Zalaudek, I.; Giuffrida, R. Coronavirus disease 2019: Facts and controversies. Dermatol. Ther. 2020, e13366, doi:10.1111/dth.13366.

12. Andersen, K.G.; Rambaut, A.; Lipkin, W.I.; Holmes, E.C.; Garry, R.F. The proximal origin of SARS-CoV-2. Nat. Med. 2020, 26, 450-452, doi:10.1038/s41591-020-0820-9.

13. Ahmad, T.; Khan, M.; Haroon; Musa, T.H.; Nasir, S.; Hui, J.; Bonilla-Aldana, D.K.; Rodriguez-Morales, A.J. COVID-19: Zoonotic aspects. Travel Med. Infect. Dis. 2020, 101607, doi:10.1016/j.tmaid.2020.101607.

14. van Doremalen, N.; Bushmaker, T.; Morris, D.H.; Holbrook, M.G.; Gamble, A.; Williamson, B.N.; Tamin, A.; Harcourt, J.L.; Thornburg, N.J.; Gerber, S.I., et al. Aerosol and Surface Stability of SARS-CoV-2 as Compared with SARS-CoV-1. N. Engl. J. Med. 2020, 382, 1564-1567, doi:10.1056/NEJMc2004973.

15. Escalera-Antezana, J.P.; Lizon-Ferrufino, N.F.; Maldonado-Alanoca, A.; Alarcon-De-la-Vega, G.; Alvarado-Arnez, L.E.; Balderrama-Saavedra, M.A.; Bonilla-Aldana, D.K.; Rodriguez-Morales, A.J.; Lancovid. Clinical features of the first cases and a cluster of Coronavirus Disease 2019 (COVID-19) in Bolivia imported from Italy and Spain. Travel Med. Infect. Dis. 2020, 101653, doi:10.1016/j.tmaid.2020.101653.

16. Lai, C.C.; Shih, T.P.; Ko, W.C.; Tang, H.J.; Hsueh, P.R. Severe acute respiratory syndrome coronavirus 2 (SARS-CoV-2) and coronavirus disease-2019 (COVID-19): The epidemic and the challenges. Int. J. Antimicrob. Agents 2020, 55, 105924, doi:10.1016/j.ijantimicag.2020.105924.

17. CDC.gov. Stop the Spread of Rumors I CDC. Availabe online: https://www.cdc.gov/coronavirus/2019-ncov/daily-life-coping/share-facts.html (accessed on 29 April 2020).

18. CDC.gov. Symptoms of Coronavirus । CDC. Availabe online: https://www.cdc.gov/coronavirus/2019-ncov/symptoms-testing/symptoms.html (accessed on 29 April 2020). 
19. Pianegonda, E. What is Kawasaki disease, what are the symptoms and is it linked to coronavirus? ABC News. Availabe online: https://www.abc.net.au/news/2020-04-29/kawasaki-disease-symptoms-is-it-linked-coronavirus-in-aus tralia/12197008 (accessed on 30 April 2020).

20. Yeager, A. Lost smell and taste hint COVID-19 can target the nervous system. Availabe online: https://www.the-scientist.com/news-opinion/lost-smell-and-taste-hint-covid-19-can-target-the-nervou S-system-67312 (accessed on 30 April 2020).

21. Kissling, S.; Rotman, S.; Gerber, C.; Halfon, M.; Lamoth, F.; Comte, D.; Lhopitallier, L.; Sadallah, S.; Fakhouri, F. Collapsing glomerulopathy in a COVID-19 patient. Kidney Int. 2020, doi:10.1016/j.kint.2020.04.006.

22. Jarvis, C. The unusual symptoms of COVID-19. Availabe online: https://www.the-scientist.com/news-opinion/the-unusual-symptoms-of-covid-19-67522 (accessed on 21 May 2020).

23. Baraniuk, C. Receptors for SARS-CoV-2 present in wide variety of human cells. Availabe online: https://www.the-scientist.com/news-opinion/receptors-for-sars-cov-2-present-in-wide-variety-of-hum an-cells-67496 (accessed on 30 April 2020).

24. Grens, K. Strokes reported among some middle-aged COVID-19 patients. Availabe online: https://www.the-scientist.com/news-opinion/strokes-reported-among-some-middle-aged-covid-19-pa tients-67482 (accessed on 30 April 2020).

25. Baig, A.M.; Khaleeq, A.; Ali, U.; Syeda, H. Evidence of the COVID-19 virus targeting the CNS: Tissue distribution, host-virus interaction, and proposed neurotropic mechanisms. ACS Chem. Neurosci. 2020, 11, 995-998, doi:10.1021/acschemneuro.0c00122.

26. Li, Y.C.; Bai, W.Z.; Hashikawa, T. The neuroinvasive potential of SARS-CoV2 may play a role in the respiratory failure of COVID-19 patients. J. Med. Virol. 2020, 92, 552-555, doi:10.1002/jmv.25728.

27. Wang, D.; Hu, B.; Hu, C.; Zhu, F.; Liu, X.; Zhang, J.; Wang, B.; Xiang, H.; Cheng, Z.; Xiong, Y., et al. Clinical characteristics of 138 hospitalized patients with 2019 novel Coronavirus-infected pneumonia in Wuhan, China. JAMA 2020, 323, 1061-1069, doi:10.1001/jama.2020.1585.

28. Oxley, T.J.; Mocco, J.; Majidi, S.; Kellner, C.P.; Shoirah, H.; Singh, I.P.; De Leacy, R.A.; Shigematsu, T.; Ladner, T.R.; Yaeger, K.A., et al. Large-vessel stroke as a presenting feature of Covid-19 in the young. N. Engl. J. Med. 2020, 382, e60, doi:10.1056/NEJMc2009787.

29. Landa, N.; Mendieta-Eckert, M.; Fonda-Pascual, P.; Aguirre, T. Chilblain-like lesions on feet and hands during the COVID-19 Pandemic. Int. J. Dermatol. 2020, 59, 739-743, doi:10.1111/ijd.14937.

30. Cholankeril, G.; Podboy, A.; Aivaliotis, V.I.; Tarlow, B.; Pham, E.A.; Spencer, S.; Kim, D.; Hsing, A.; Ahmed, A. High prevalence of concurrent gastrointestinal manifestations in patients with SARS-CoV-2: Early experience from California. Gastroenterology 2020, doi:10.1053/j.gastro.2020.04.008.

31. Mumm, J.N.; Osterman, A.; Ruzicka, M.; Stihl, C.; Vilsmaier, T.; Munker, D.; Khatamzas, E.; Giessen-Jung, C.; Stief, C.; Staehler, M., et al. Urinary frequency as a possibly overlooked symptom in COVID-19 patients: Does SARS-CoV-2 cause viral cystitis? Eur. Urol. 2020, doi:10.1016/j.eururo.2020.05.013.

32. Menni, C.; Valdes, A.M.; Freidin, M.B.; Sudre, C.H.; Nguyen, L.H.; Drew, D.A.; Ganesh, S.; Varsavsky, T.; Cardoso, M.J.; El-Sayed Moustafa, J.S., et al. Real-time tracking of self-reported symptoms to predict potential COVID-19. Nat. Med. 2020, doi:10.1038/s41591-020-0916-2. 
33. Rogers, J.P.; Chesney, E.; Oliver, D.; Pollak, T.A.; McGuire, P.; Fusar-Poli, P.; Zandi, M.S.; Lewis, G.; David, A.S. Psychiatric and neuropsychiatric presentations associated with severe coronavirus infections: a systematic review and meta-analysis with comparison to the COVID-19 pandemic. Lancet Psychiatry 2020, 7, 611-627, doi:10.1016/S2215-0366(20)30203-0.

34. Wu, H.; Larsen, C.P.; Hernandez-Arroyo, C.F.; Mohamed, M.M.B.; Caza, T.; Sharshir, M.; Chughtai, A.; Xie, L.; Gimenez, J.M.; Sandow, T.A., et al. AKI and collapsing glomerulopathy associated with COVID-19 and APOL1 high-risk genotype. J. Am. Soc. Nephrol. 2020, ASN.2020050558, doi:10.1681/ASN.2020050558.

35. Nasr, S.H.; Kopp, J.B. COVID-19-associated collapsing glomerulopathy: An emerging entity. Kidney Int. Rep. 2020, doi:10.1016/j.ekir.2020.04.030.

36. Peleg, Y.; Kudose, S.; D'Agati, V.; Siddall, E.; Ahmad, S.; Kisselev, S.; Gharavi, A.; Canetta, P. Acute kidney injury due to collapsing glomerulopathy following COVID-19 infection. Kidney Int. Rep. 2020, 5 , 940-945, doi:10.1016/j.ekir.2020.04.017.

37. Rahimi, F.; Talebi Bezmin Abadi, A. Inhibitors of angiotensin-converting enzyme or blockers of angiotensin-2 receptor in COVID-19 patients with comorbid cardiovascular or pulmonary diseases. Research in Molecular Medicine 2020, 8, 0-0.

38. Yan, R.; Zhang, Y.; Li, Y.; Xia, L.; Guo, Y.; Zhou, Q. Structural basis for the recognition of SARS-CoV-2 by full-length human ACE2. Science 2020, 367, 1444-1448, doi:10.1126/science.abb2762.

39. Rahimi, F.; Talebi Bezmin Abadi, A. Challenges of managing the asymptomatic carriers of SARS-CoV-2. Travel Med. Infect. Dis. 2020, 101677, doi:10.1016/j.tmaid.2020.101677.

40. He, X.; Lau, E.H.Y.; Wu, P.; Deng, X.; Wang, J.; Hao, X.; Lau, Y.C.; Wong, J.Y.; Guan, Y.; Tan, X., et al. Temporal dynamics in viral shedding and transmissibility of COVID-19. Nat. Med. 2020, 26, 672-675, doi:10.1038/s41591-020-0869-5.

41. Remuzzi, A.; Remuzzi, G. COVID-19 and Italy: what next? Lancet 2020, 395, 1225-1228, doi:10.1016/S0140-6736(20)30627-9.

42. Porcheddu, R.; Serra, C.; Kelvin, D.; Kelvin, N.; Rubino, S. Similarity in Case Fatality Rates (CFR) of COVID-19/SARS-COV-2 in Italy and China. J. Infect. Dev. Ctries. 2020, 14, 125-128, doi:10.3855/jidc.12600.

43. Hellewell, J.; Abbott, S.; Gimma, A.; Bosse, N.I.; Jarvis, C.I.; Russell, T.W.; Munday, J.D.; Kucharski, A.J.; Edmunds, W.J.; Centre for the Mathematical Modelling of Infectious Diseases, C.-W.G., et al. Feasibility of controlling COVID-19 outbreaks by isolation of cases and contacts. Lancet Glob Health 2020, 8, e488-e496, doi:10.1016/S2214-109X(20)30074-7.

44. Wilder-Smith, A.; Freedman, D.O. Isolation, quarantine, social distancing and community containment: pivotal role for old-style public health measures in the novel coronavirus (2019-nCoV) outbreak. J. Travel Med. 2020, 27, taaa020, doi:10.1093/jtm/taaa020.

45. Metcalf, C.J.E.; Ferrari, M.; Graham, A.L.; Grenfell, B.T. Understanding herd immunity. Trends Immunol. 2015, 36, 753-755, doi:10.1016/j.it.2015.10.004.

46. Smith, D.R. Herd Immunity. Vet. Clin. North Am. Food Anim. Pract. 2019, 35, 593-604, doi:10.1016/j.cvfa.2019.07.001.

47. Armitage, R.; Hawke, J. What is herd immunity and could it slow the spread of coronavirus COVID-19 around the world? Availabe online: https://www.abc.net.au/news/2020-03-19/what-is-herd-immunity-and-could-it-stop-coronavirus/1205 9968 (accessed on 7 April 2020). 
48. Boseley, S. Herd immunity: will the UK's coronavirus strategy work? Availabe online: https://www.theguardian.com/world/2020/mar/13/herd-immunity-will-the-uks-coronavirus-strategywork (accessed on 7 April 2020).

49. Chandrashekar, A.; Liu, J.; Martinot, A.J.; McMahan, K.; Mercado, N.B.; Peter, L.; Tostanoski, L.H.; Yu, J.; Maliga, Z.; Nekorchuk, M., et al. SARS-CoV-2 infection protects against rechallenge in rhesus macaques. Science 2020, eabc4776, doi:10.1126/science.abc4776.

50. Erasmus, J.H.; Khandhar, A.P.; Walls, A.C.; Hemann, E.A.; O'Connor, M.A.; Murapa, P.; Archer, J.; Leventhal, S.; Fuller, J.; Lewis, T., et al. Single-dose replicating RNA vaccine induces neutralizing antibodies against SARS-CoV-2 in nonhuman primates. bioRxiv 2020, doi:10.1101/2020.05.28.121640.

51. Kellam, P.; Barclay, W. The dynamics of humoral immune responses following SARS-CoV-2 infection and the potential for reinfection. J. Gen. Virol. 2020, doi:10.1099/jgv.0.001439.

52. Zimmer, K. What do antibody tests for SARS-CoV-2 tell us about immunity? Availabe online: https://www.the-scientist.com/news-opinion/what-do-antibody-tests-for-sars-cov-2-tell-us-about-im munity--67425 (accessed on 3 July 2020).

53. Heidt, A. Studies report rapid loss of COVID-19 antibodies. Availabe online: https://www.the-scientist.com/news-opinion/studies-report-rapid-loss-of-covid-19-antibodies-67650 (accessed on 3 July 2020).

54. Fanelli, D.; Piazza, F. Analysis and forecast of COVID-19 spreading in China, Italy and France. Chaos Solitons Fractals 2020, 134, 109761, doi:10.1016/j.chaos.2020.109761.

55. Rahimi, F.; Talebi Bezmin Abadi, A. Ethical and sensible dissemination of information during the COVID-19 pandemic. Am. J. Bioeth. 2020, 1-3, doi:10.1080/15265161.2020.1761200.

56. Kwok, K.O.; Lai, F.; Wei, W.I.; Wong, S.Y.S.; Tang, J.W.T. Herd immunity - estimating the level required to halt the COVID-19 epidemics in affected countries. J. Infect. 2020, 80, e32-e33, doi:10.1016/j.jinf.2020.03.027.

57. Worldometer. Coronavirus (COVID-19) mortality rate. Availabe online: https://www.worldometers.info/coronavirus/ (accessed on 3 July 2020).

58. British Society for Immunology. BSI response to herd immunity and SARS-CoV-2. Availabe online: https://www.immunology.org/news/bsi-response-herd-immunity-and-sars-cov-2 (accessed on 3 July 2020).

59. Tang, X.; Wu, C.; Li, X.; Song, Y.; Yao, X.; Wu, X.; Duan, Y.; Zhang, H.; Wang, Y.; Qian, Z. On the origin and continuing evolution of SARS-CoV-2. Natl. Sci. Rev. 2020.

60. Su, Y.; Anderson, D.; Young, B.; Zhu, F.; Linster, M.; Kalimuddin, S.; Low, J.; Yan, Z.; Jayakumar, J.; Sun, L. Discovery of a 382-nt deletion during the early evolution of SARS-CoV-2. bioRxiv 2020, doi:10.1101/2020.03.11.987222.

61. Ramsey, L. Here's why experts are worried we won't have enough hospital beds to handle a surge of coronavirus patients. Availabe online: https://www.businessinsider.com/coronavirus-hospital-beds-per-capita-us-south-korea-italy-2020-3 (accessed on 7 April 2020).

62. Alltucker, K.; Penzenstadler, N. Too many coronavirus patients, too few ventilators: Outlook in US could get bad, quickly. Availabe online: https://www.usatoday.com/story/news/health/2020/03/18/coronavirus-ventilators-us-hospitals-johnshopkins-mayo-clinic/5032523002/ (accessed on 7 April 2020). 
9 of 9

63. Samson, M. Relief and sadness as Tokyo Olympic postponed to 2021. Availabe online: https://www.capitalethiopia.com/sports/relief-and-sadness-as-tokyo-olympic-postponed-to-2021/ (accessed on 7 April 2020). 